\title{
Did the first farmers of central and eastern Europe produce dairy foods?
}

\author{
Oliver E. Craig ${ }^{1}$, John Chapman ${ }^{2}$, Carl Heron ${ }^{3}$, Laura H. Willis ${ }^{3}$, \\ László Bartosiewicz ${ }^{4}$, Gillian Taylor ${ }^{5}$, Alasdair Whittle ${ }^{6} \&$ \\ Matthew Collins ${ }^{7}$
}

Although the origins of domestic animals have been well-documented, it is unclear when livestock were first exploited for secondary products, such as milk. The analysis of remnant fats preserved in ceramic vessels from two agricultural sites in central and eastern Europe dating to the Early Neolithic (5900-5500 cal BC) are best explained by the presence of milk residues. On this basis, the authors suggest that dairying featured in early European farming economies. The evidence is evaluated in the light of analysis of faunal remains from this region to determine the scale of dairying. It is suggested that dairying — perhaps of sheep or goats - was initially practised on a small scale and was part of a broad mixed economy.

Keywords: dairying, lipids, stable isotopes, ceramic, faunal remains

\section{Introduction}

In human dietary evolution, the inception of nutritious and storable dairy foods was a significant adaptation. Whether as part of a pastoral or a broader integrated economy, dairying is also economically advantageous, as it provides an extremely efficient means of exploiting ruminant animals (Holmes 1970; Legge 1981). However, the origins of this practice are unclear. One theory is that dairying developed as part of a set of inter-connected innovations, also comprising additional 'secondary products' such as the use of animal traction for ploughing and for the cart, and the production of woollen garments. In this scenario, these innovations are thought to have transformed the economic basis of the Near East in the fourth millennium BC and Europe in the third millennium BC (Sherratt 1981, 1983, 1997: 199-228). Whilst various forms of artefactual evidence do lend support to this hypothesis (Sherratt 1981), critiques of the 'secondary products revolution' have ranged

\footnotetext{
1 Ancient Biomolecules Group, Drummond Building, University of Newcastle upon Tyne, NE4 5PD, UK. Current address for correspondence: Centro di antropologia molecolare per lo studio del DNA antico, Dipartimento di Biologia, Università di Roma "Tor Vergata"00133 Roma, Italy (Email: oliver.craig@uniroma2.it)

2 Department of Archaeology, University of Durham, South Road, Durham DH1 3LE, UK

3 Department of Archaeological Sciences, University of Bradford, Bradford BD7 1DP, UK

4 Institute of Archaeological Sciences, Eötvös Loránd University, Budapest, Hungary

5 Ancient Biomolecules Group, Drummond Building, University of Newcastle upon Tyne, NE4 5PD, UK

6 School of History and Archaeology, Cardiff University, Humanities Building, Colum Drive, Cardiff, CF10 $3 E U$, UK

7 BioArch, Departments of Biology \& Archaeology, University of York, BOX 373, York, YO10 5YW, UK
} 


\section{O.E. Craig et al.}

from disputes over chronology (Chapman 1982; Bogucki 1984a), taphonomy (Chapman 1982), subsistence practices (Whittle 1985: 209-10) and ideology (Hodder 1990).

An alternative theory, and one favoured by many critics, is that dairying was an integral part of mixed agro-pastoral practices from a far earlier period. In this scenario dairying is related to the spread of exotic domestic animal species, sheep and goat, from the Near East into Europe during the seventh millennium cal BC and possibly combined with the keeping of locally domesticated cattle (Bökönyi 1974: 28). In the absence of clear artefactual evidence, demonstrating an early origin for dairying is difficult and is further complicated by problems of interpreting fragmented faunal assemblages (Halstead 1998). It has long been recognised that molecular and isotopic analysis of remnant organic matter trapped within the fabric of pottery sherds has the potential to transform dietary and economic investigations of the past (Hodder 1990: 204; Sherratt 1997: 13). Although claims for the detection of milk in pottery have been made since the early 1930s (e.g. Grüss 1933), the specificity of the compounds identified in these early studies is questionable. More recently, compound-specific stable carbon isotopic measurements of mid-chain fatty acids have been used to reliably identify degraded dairy lipids (Dudd \& Evershed 1998). Using this method, dairy products have been identified in ceramics dating from the Early Neolithic to Iron Age in the UK (Dudd et al. 1999; Copley et al. 2003), giving support to an early origin of dairying and opening up the possibility of tracing dairy products to some of the earliest European ceramic assemblages. Here, we aim to test the hypothesis that dairying was practised by some of Europe's earliest farming groups by examining a range of pottery vessels from sites dating to the Early Neolithic of central and eastern Europe (5900-5500 cal BC).

\section{Samples}

Early Neolithic ceramics were obtained from two settlement sites:

1. Schela Cladovei, located on the left bank of the Danube (the Romanian side), downstream of the Iron Gates gorge and occupied during the Mesolithic and Neolithic from $7500 \mathrm{cal}$ BC to $5300 \mathrm{cal} \mathrm{BC}$, with a break in occupation between 6300 and $5950 \mathrm{cal} \mathrm{BC}$ (Boroneant et al. 1999; Bonsall et al. 2002). The pottery sampled in this study dates to the Early Neolithic (a late phase of the Starčevo-Criş culture) between 5950 and $5500 \mathrm{cal} \mathrm{BC.}$

2. Ecsegfalva 23, a small Körös culture site in the centre of the Great Hungarian Plain, occupied, most likely permanently, between 5800 and $5700 \mathrm{cal} \mathrm{BC} \mathrm{(Whittle} \mathrm{forthcoming;}$ Whittle 2000; Bronk Ramsey et al. forthcoming). A range of open and closed bowls and necked jars, typical of the Körös culture were sampled (full details in Oross forthcoming).

Both of these sites lie in riverine environments in the Danube basin (Figure 1); the former is located on a river terrace of the Danube, backed by fertile soils, while the latter lies in an area rich in fertile loess soils and where some of the earliest farming communities were established in Europe. Significantly, the Neolithic cultures that developed in this region and further to the south-east, during the seventh and first half of the sixth millennia BC, are thought to have influenced the development of agriculture and pastoralism in other parts of 


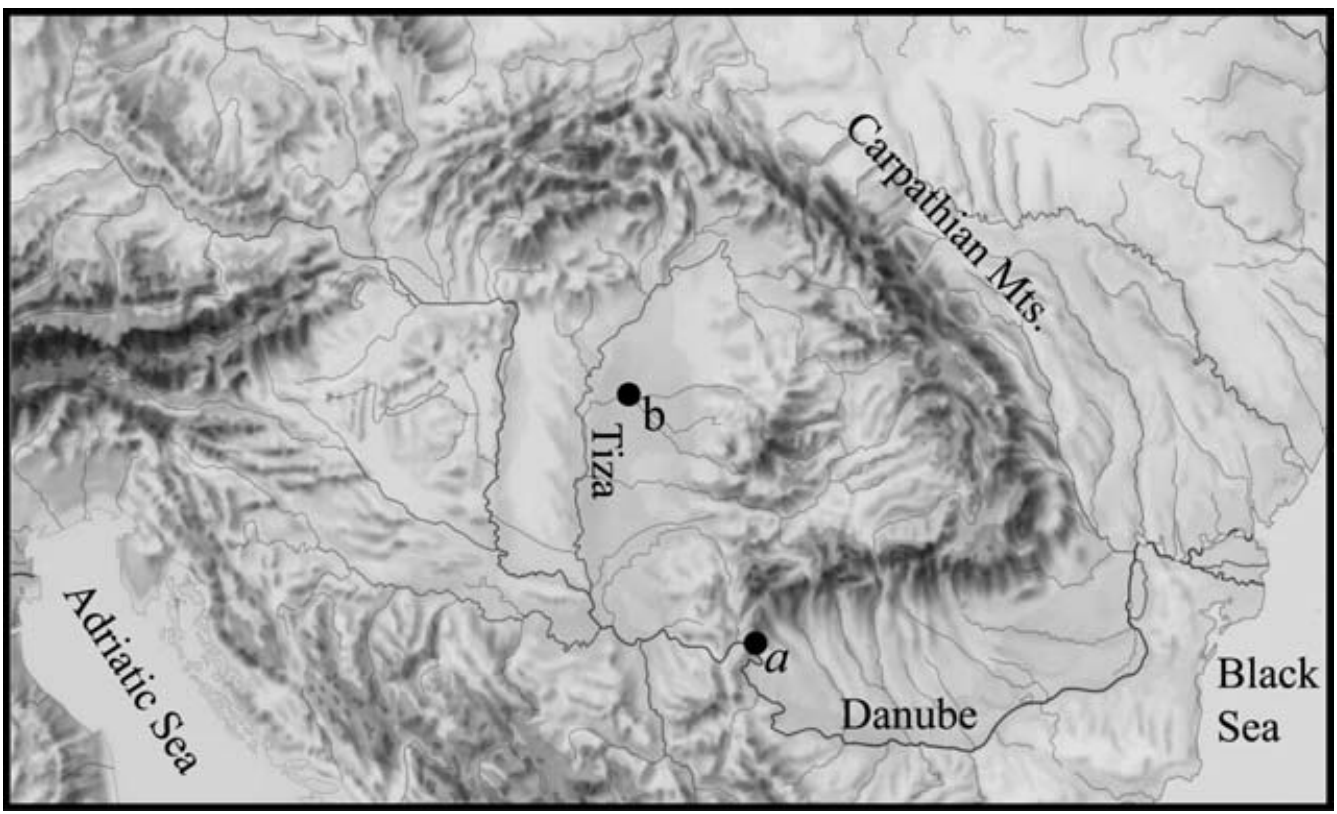

Figure 1. Map showing approximate location of sites discussed in the text. (a) Schela Cladovei; (b) Ecsegfalva. Map courtesy of Zentai László, 1996.

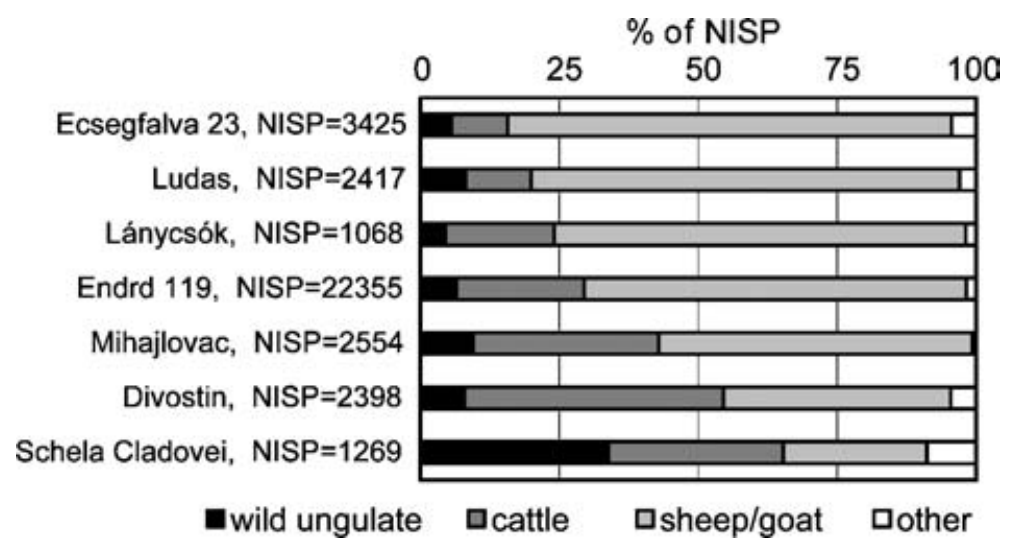

Figure 2. Ungulates exploited for meat at major early Neolithic sites in central and eastern Europe. The upper four sites are located in the Great Hungarian Plain (Bartosiewicz forthcoming; Bökönyi 1974, 1981, 1992a), Divostin (Bökönyi 1988) in central Serbia and Schela Cladovei (Bartosiewicz et al. 2001) and Mihajlovac (Bökönyi 1992b) in the Iron Gates Gorge. NISP — number of identifiable specimens.

central Europe, as well as north-west Europe during the following two millennia, either by the dispersal of farming populations (Bogucki 1996) or through the adoption of farming by indigenous foragers (Whittle 1996). The faunal assemblages at each site are dominated by domesticated sheep and goat and to a lesser extent cattle (Figure 2). Notably at the earlier sites, especially Schela Cladovei, wild animals were also exploited for meat, indicating a continuation of earlier subsistence practices. From these sites, lipids were extracted from 49 typical Early Neolithic ceramic vessels including bowls, dishes, amphorae and jars (8 from 


\section{O.E. Craig et al.}

Schela Cladovei; 41 from Ecsegfalva). These were analysed by gas chromatography (GC), gas chromatography mass spectrometry (GCMS) and gas chromatography combustion isotope ratio mass spectrometry (GC-C-IRMS) using standard procedures (see note).

\section{Methodological rationale}

Fresh or exceptionally well preserved dairy fats can be easily identified by the presence of diagnostic short-chain fatty acids and broad distributions of triacylglycerols (with 28-54 acyl carbon atoms) using GCMS. However, during exposure to the burial environment, the lower molecular mass diagnostic compounds are either lost completely or else their distribution is significantly altered. Laboratory experiments have shown that dairy fats degrade so as to more closely resemble adipose fats (Dudd \& Evershed 1998). This has been overcome by determining differences in the stable carbon isotope ratios $\left(\delta^{13} \mathrm{C}\right.$ values $)$ of the major saturated fatty acids (with carbon chain lengths of 16 [C16:0; palmitic acid] and of 18 [C18:0; stearic acid]) using GC-C-IRMS (Dudd \& Evershed 1998; Dudd et al. 1999). Due to differences in the way that lipids are biosynthesised and routed to different tissues (Moore \& Christie 1981), it is possible to distinguish ruminant dairy fats, ruminant adipose fats and non-ruminant adipose fats using these criteria (Copley et al. 2003; Figure 3a). The absolute carbon isotope ratios $\left(\delta^{13} \mathrm{C}\right.$ values) of $\mathrm{C} 16$ and $\mathrm{C} 18$ fatty acids in milk are a function of the animal's diet (see Figure 3a), but in all cases the $\delta^{13} \mathrm{C}$ value of the C18:0 fatty acid is between 3.3-7.0\% lighter than the $\mathrm{C} 16: 0$ component thus providing a criterion for discriminating dairy products (Copley et al. 2003; Figures 3a, b); this difference is commonly expressed as $\Delta^{13} \mathrm{C}$, where $\Delta^{13} \mathrm{C}=\left(\delta^{13} \mathrm{C}_{18: 0}\right)-\left(\delta^{13} \mathrm{C}_{16: 0}\right)$.

\section{Results}

Sherds yielding lipid residues are summarised in Table 1. Five sherds of the eight analysed from Schela Cladovei contained measurable amounts of absorbed lipid. The lipid yields were low $\left(<0.2 \mathrm{mg} \mathrm{g}^{-1}\right)$; intact acyl lipids and significant quantities of unsaturated fatty acids were only observed in one sample (Table 1). However, GC-C-IRMS analysis indicates that these lipids derive from a diverse number of sources (Figures $3 a, b$ ). Extracts from two sherds have $\Delta^{13} \mathrm{C}$ values consistent with the reference ruminant milk fat values reported here (Figure 3b) and those previously published (Copley et al. 2003). Of the remaining three sherds, the $\Delta^{13} \mathrm{C}$ of two indicate the presence of non-ruminant fats $\left(\Delta^{13} \mathrm{C}\right.$ between -1 and $2 \%$ ) possibly from the exploitation of pigs or freshwater fish from the Danube, whilst the third is consistent with values obtained from ruminant adipose fat $\left(\Delta^{13} \mathrm{C}\right.$ between -3.3 and $-1 \%$; Copley et al. 2003).

Seven out of forty-one samples from Ecsegfalva contained detectable amounts of lipids. With the exception of one sherd (ec-9664, $\sim 1.37 \mathrm{mg} \cdot \mathrm{g}^{-1}$ ) the quantities of lipid were low (mean $\sim 0.18 \mathrm{mg} \cdot \mathrm{g}^{-1}$ ). Nevertheless, the amount of lipid absorbed in interior sherd surfaces was much greater than in the exterior samples indicating that the lipid is associated with vessel use. The triacylglycerol distribution (Figure 3b), as well as high abundances of C18:0, indicate the presence of degraded animal fats (Enser 1991). In addition, saturated fatty acids with branched and odd-number carbon chains (e.g. C17:0; C17:0 Br) were detected in all 
a
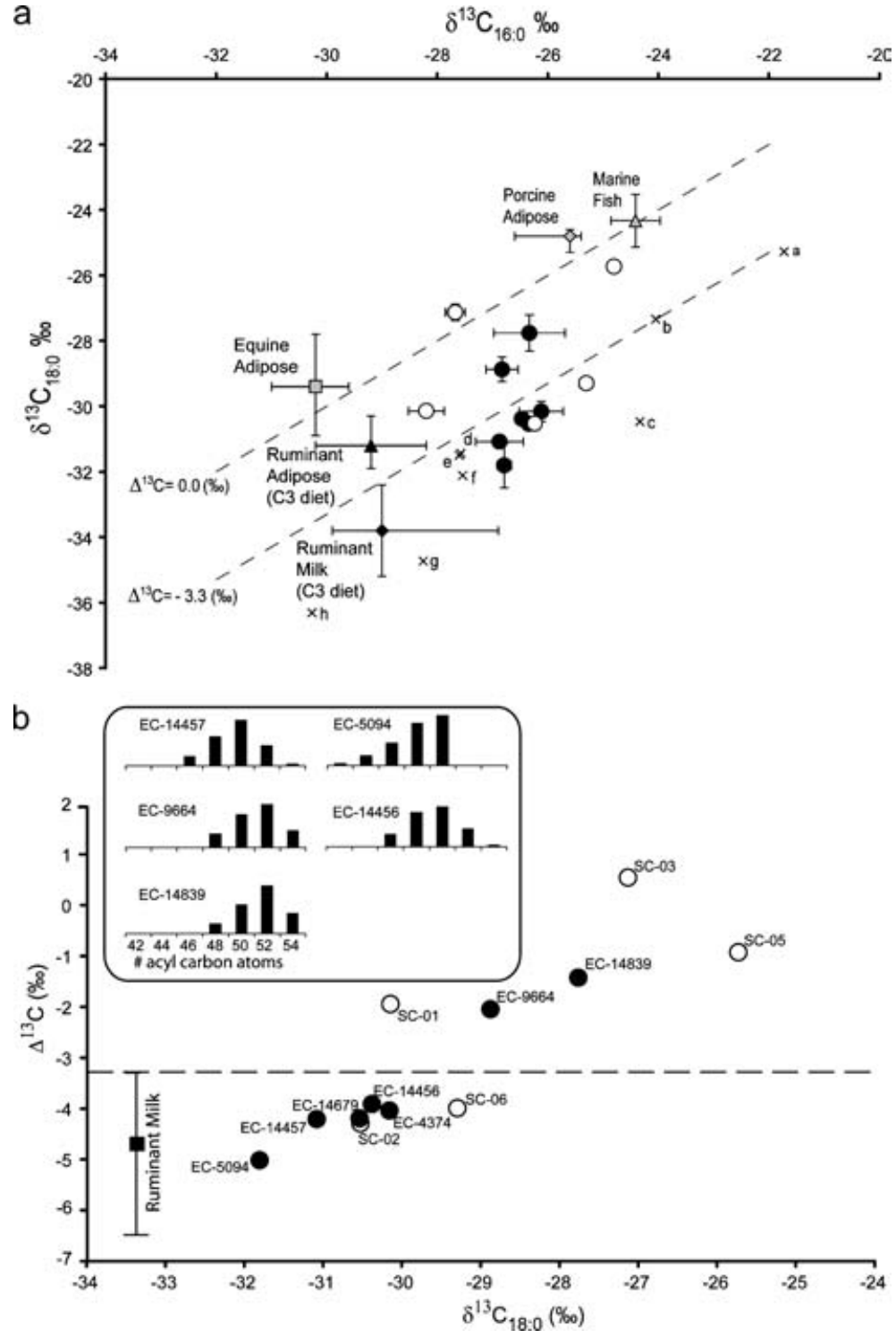

Figure 3. (a) Plot of the $\delta^{13} \mathrm{C}$ values of C18:0 and C16:0 fatty acids extracted from various Early Neolithic potsherds control samples and reference milk fats. The later were obtained by solvent extraction from; (a) a modern milk pot from north-western India; (b) sheep's milk from northern England, animals fed supplementary C4 fodders; (c) cow's milk from northern England, animals fed c. 60 per cent maize silage; (d) goat's milk from northern England, animals fed supplementary C4 fodders; (e) boiled cow's milk from northern England, animals fed supplementary C4 fodders; $(f)$ cow's milk from southern India, animals fed c. 65 per cent rice bran and 35 per cent sorghum; (g) cow's milk from northern England, animals grazed on purely C3 pasture (same herd as c); (h) cow's milk from the Shetland Islands, animals grazed on purely C3 pasture. Despite the variation in these animals diet and geographical location, the $\Delta^{13} C$ values are always less than $-3.3 \%$ (indicated by lower dashed line). Mean and standard deviations $(1 \sigma)$ are shown for each of the pottery extracts which was calculated by assessing machine precision and overall accuracy from analysis of multiple extracts. These data are further compared with ratios for mammalian reference fats from Dudd et al. (1999: Figure 3) and oils from marine fish $(n=4)$, the range and mean values are shown. All the modern samples have been corrected for the effects of fossil fuel burning (Fredli et al. 1986). Open circles - Schela Cladovei, solid circles - Ecsegfalva. 


\section{O.E. Craig et al.}

of the sherds, except ec-14839. These lipids are characteristic of fats from ruminant animals and this was confirmed by GC-C-IRMS analysis. In each case the $\Delta^{13} \mathrm{C}$ values indicate that ruminant milk fats, ruminant adipose fats or a mixture of these products were processed in these vessels (Figure 3b).

The presence of intact triacylglycerols in several of these sherds (Figure $3 \mathrm{~b}$ ) is remarkable considering the length of exposure in the burial environment $(c .7 .5 \mathrm{ka})$. Whilst it is likely that only components with the highest molecular mass from the original suite of triacylglycerols remain, the presence of components with less than 48 carbon atoms (Figure 3) identified in three of the sherds is further indication that these absorbed residues derive from ruminants. Triacylglycerols with less than 48 carbon atoms are at very low abundance in non-ruminant fats (Enser 1991). Three of the Ecsegfalva sherds also contained a range of unbranched mid-chain ketones (Table 1). These are formed by heatinduced condensation of free fatty acids within the vessel wall (Evershed et al. 1995; Raven et al. 1997). No correlation was observed between sherds containing ketones and exterior sooting.

Whilst we are confident that we have identified dairy products on these sherds, several points need clarification:

1. We report the maximum uncertainties in the isotope ratios for each of the pottery extracts in Figure 3a (error bars). These take into account uncertainties associated with both instrument precision and, where available (see Table 1), analyses of second extracts. At the 95 per cent confidence interval, the variance of $\Delta^{13} \mathrm{C}$ values obtained by repeated measurements of individual samples identified as containing dairy products, plot within the range of our reference milk fats (mean $\sim-4.7 \%$ (standard deviation $[1 \sigma] \sim 1.3 \%$ ) $)$ and those previously reported by Dudd et al. (1999). They do not plot within the range produced by analysis of other ruminant tissues (with the possible exception of deer fats, see below).

2. Whilst sherds from both sites containing milk fat have $\Delta^{13} \mathrm{C}$ values consistent with the reference ruminant milk fat values, reported by Dudd et al. (1999), the absolute $\delta^{13} \mathrm{C}$ values for both fatty acids are enriched by $c .2 \%$ (Figure 3a). We demonstrate (Figure 3a) that dietary supplements have a dramatic effect on dairy fatty acid $\delta^{13} \mathrm{C}$ values, although crucially do not alter the $\Delta^{13} \mathrm{C}$ value (Figure $3 \mathrm{~b}$ ). As the previously published modern reference samples were obtained from animals raised on $\mathrm{C} 3$ pasture from southern England, it is plausible that variation in geographical location and/or diet may explain this discrepancy. Our hypothesis is supported by stable carbon isotope ratios from bone collagen $\left(\delta^{13} \mathrm{C}_{\text {coll }}\right)$ which provides an independent measurement of animal diet. Stable carbon isotope ratios of Neolithic ruminants (21 sheep/goat; 3 cattle) from

(b) Plot of the offset in $\delta^{13} C$ values of C18:0 and C16:0 fatty acids ( ${ }^{13} C$ value) against the $\delta^{13} C$ value of the C18:0 fatty acid extracted from various Early Neolithic potsherds. $\Delta^{13}$ C values which plot below the dashed line (i.e. $<-3.3 \%$ ) indicate the presence of ruminant milk. The range and mean $\Delta^{13} C$ values obtained from the reference milk fats plotted in Figure $3 a$ is shown (plotted on Y-axis only). These $\Delta^{13} C$ values are consistent with those obtained by Copley et al. (2003). Inset triacylglycerol distributions of the Ecsegfalva pottery samples. The distributions are typical of animal fats. A wide distribution of triacylglycerols (C42-C54) is indicative of ruminant fats whilst a narrow distribution (C48-C54) is more consistent with non-ruminant fats. The chromatographic conditions did not allow the identification of the triacylglycerols with the number of acyl carbon atoms $>50$ in sample EC-5094. 
Dairy food production in Europe

Table 1. Summary of results on sherds containing detectable amounts of lipid

\begin{tabular}{|c|c|c|c|c|c|c|}
\hline Sample \# & $\begin{array}{l}\text { Vessel/ } \\
\text { Context }\end{array}$ & Sample Description & Lipids Detected & $\begin{array}{l}\delta^{13} \mathrm{C}_{16: 0} \\
(\% o)\end{array}$ & $\begin{array}{l}\delta^{13} \mathrm{C}_{18: 0} \\
(\% o)\end{array}$ & $\begin{array}{l}\Delta^{13} \mathrm{C} \\
(\% o)\end{array}$ \\
\hline \multicolumn{7}{|c|}{ Schela Cladovei } \\
\hline \multirow[t]{2}{*}{ sc-001 } & \multirow[t]{2}{*}{2377} & $\begin{array}{l}\text { Rim fragment from decorated } \\
\text { necked amphora }\end{array}$ & FA, MAG, DAG & -28.2 & -30.1 & -1.9 \\
\hline & & Exterior of above & $\mathrm{n} / \mathrm{d}$ & - & - & - \\
\hline sc- $002^{*}$ & 4268 & $\begin{array}{l}\text { Body fragment of black on } \\
\text { red painted ware, probably } \\
\text { a rounded bowl }\end{array}$ & FA & -26.2 & -30.5 & -4.3 \\
\hline sc-003 & 4372 & $\begin{array}{l}\text { Body fragment from } \\
\text { decorated vessel, probably } \\
\text { an amphora }\end{array}$ & FA & -27.7 & -27.1 & 0.5 \\
\hline sc- -005 & 2508 & Body fragment, form unknown & FA & -24.8 & -25.7 & -0.9 \\
\hline sc-006 & A3/U3/F4 & $\begin{array}{l}\text { Body fragment from amphora } \\
\text { Base of above }\end{array}$ & $\begin{array}{l}\mathrm{FA} \\
\mathrm{n} / \mathrm{d}\end{array}$ & $\begin{array}{l}-25.3 \\
-\end{array}$ & $\begin{array}{l}-29.3 \\
-\end{array}$ & $\begin{array}{l}-4.0 \\
-\end{array}$ \\
\hline \multicolumn{7}{|c|}{ Ecsegfalva } \\
\hline ec-14456* & $23 \mathrm{~B}$ & $\begin{array}{l}\text { Thin walled, plain rim sherd } \\
\text { Exterior of above }\end{array}$ & $\begin{array}{l}\text { FA, KT, TAG } \\
\text { n/d }\end{array}$ & $\begin{array}{l}-26.5 \\
-\end{array}$ & $\begin{array}{l}-30.4 \\
-\end{array}$ & $\begin{array}{l}-3.9 \\
-\end{array}$ \\
\hline \multirow[t]{2}{*}{ ec-14457 } & $23 \mathrm{~B}$ & $\begin{array}{l}\text { Thin walled body fragment } \\
\text { Relief pattern }\end{array}$ & FA, KT, TAG & -26.9 & -31.1 & -4.2 \\
\hline & & Exterior of above & $\mathrm{n} / \mathrm{d}$ & - & - & - \\
\hline \multirow[t]{2}{*}{ ec-14839* } & $23 \mathrm{~B}$ & $\begin{array}{l}\text { Medium walled plain rim } \\
\text { fragment with a smooth } \\
\text { finish }\end{array}$ & FA, TAG & -26.3 & -27.8 & -1.4 \\
\hline & & Exterior of above & $\mathrm{n} / \mathrm{d}$ & - & - & - \\
\hline \multirow[t]{2}{*}{ ec-9664 } & $23 \mathrm{C}$ & $\begin{array}{l}\text { Thick walled, body fragment. } \\
\text { Incised pattern on outer } \\
\text { surface }\end{array}$ & FA, KT, TAG & -26.8 & -28.9 & -2.0 \\
\hline & & Exterior of above & $\mathrm{n} / \mathrm{d}$ & - & - & - \\
\hline ec-5094* & $23 \mathrm{~B}$ & Thick walled body fragment & FA, TAG & -26.8 & -31.8 & -5.0 \\
\hline ec- $4374^{*}$ & $23 \mathrm{~B}$ & $\begin{array}{l}\text { Medium walled base } \\
\text { fragment }\end{array}$ & FA, TAG(tr) & -26.1 & -30.2 & -4.0 \\
\hline ec-14679 & $23 \mathrm{~B}$ & Medium walled base fragment & FA & -26.3 & -30.5 & -4.2 \\
\hline
\end{tabular}

Lipids were extracted with chloroform/methanol (2:1) and derivatised with N,O-bis(trimethylsilyl) tetrafluoroacetamide containing $1 \%(\mathrm{v} / \mathrm{v})$ trimethylchlorosilane. The resulting trimethylsilyl derivatives were analysed on a Hewlett Packard 5890 gas chromatograph with a $15 \mathrm{~m} \times 0.32 \mathrm{~mm}$, bonded-phase fused-silica capillary column coated with DB-1HT stationary phase connected to a Hewlett Packard 5972 mass spectrometer. Temperature programming was from $50^{\circ} \mathrm{C}-220^{\circ} \mathrm{C}$ at $10^{\circ} \mathrm{C} \mathrm{min}{ }^{-1}$; $220^{\circ} \mathrm{C}-340^{\circ} \mathrm{C}$ at $1^{\circ} \mathrm{C} \mathrm{min}^{-1}$.

Electron impact spectra were obtained with full scan from $50-700 \mathrm{~m} / \mathrm{z}$.

$\mathrm{n} / \mathrm{d}=$ none detected. $\mathrm{FA}=$ fatty acids, $\mathrm{DAG}=$ diacylglycerols, $\mathrm{TAG}=$ triacylglycerols, $\mathrm{KT}=$ ketones, $\operatorname{tr}=\operatorname{trace}$.

* - indicates that sherds were re-extracted.

Soil samples (not shown) either produced no lipid or very small amounts of degraded plant lipid; there was no evidence for migration of soil lipid into the sherds.

Serbia and Hungary have a mean $\delta^{13} \mathrm{C}_{\text {coll }}$ of -19.9 and a standard deviation $[1 \sigma]$ of 0.4 (Whittle et al. 2002) which is significantly enriched compared with measurements made on Neolithic ruminants ( 9 cattle; 2 sheep/goat) from southern England; mean $\delta^{13} \mathrm{C}_{\text {coll }}$ of -21.4 , standard deviation [ $1 \sigma]$ of 0.5 (Richards et al. 2000). 


\section{O.E. Craig et al.}

3. One other ruminant source for the lipid residue that must be considered is deer adipose tissue. Published isotopic values of reference deer fatty acids are rare but those available suggest some degree of overlap with milk fat values (Evershed et al. 2002; cf. Figure 2). We have measured wild Scottish venison with mean values for $\delta^{13} \mathrm{C}_{18: 0} \sim-30.9 \%$ o $(1 \sigma \sim 0.2)$ and $\delta^{13} \mathrm{C}_{16: 0} \sim-35.5 \%$ ( $\left.1 \sigma \sim 0.2\right)$, hence $\Delta^{13} \mathrm{C}=-4.6 \%$. At Ecsegfalva, we may rule out this potential source, as deer were hardly exploited (Figure 2). At Schela Cladovei, deer were exploited to a considerable degree (13 per cent of NISP; Bartosiewicz et al. 2001) and although none of the isotope values of fatty acids recovered from these vessels plot within the range of the reference deer fat values, some geographical variation must be considered (again all the deer reference values are from animals reared in the UK). No isotope measurements have been made on deer bones from Schela Cladovei although there are two published values $\left(\delta^{13} \mathrm{C}_{\text {coll }} \sim-20.8 \% \circ \&-22.2 \%\right.$ o $)$ from Padina also situated in the Iron Gates Gorge and dating to approximately the same period. We suggest that if representative, the bone protein values of deer from the Iron Gates are too isotopically light to correspond to the fatty acids present in the pottery which instead are more likely derived from the milk of domestic ruminants (see above).

\section{Discussion}

The presence of milk fats, albeit associated with a small number of vessels, indicates that dairying was practised by some of the earliest European farming communities. From a diffusionist perspective, these findings lend support to the idea that the antiquity of dairying lies with the origins of animal domestication in south-west Asia some two millennia earlier, prior to its transmission to Europe in the seventh millennium BC rather than it being a later and entirely European innovation. However, organic analyses of Early Neolithic ceramic assemblages in south-western Asia are essential in order to determine this. It should also be noted that the identification of small-scale dairying in the Early Neolithic does not rule out the later intensification in the Copper and Bronze Ages, as originally outlined in the secondary products scenario (Sherratt 1981; Greenfield 1988). In a revision to his original paper (1997; 199-208), Sherratt actually suggests that small scale dairying may have preceded the arrival of other innovations, which subsequently promoted an increase in the scale of dairying in the fourth and third millennia BC. However, in addition to the data reported here, the production of fired clay hubbed wheel models in the Late Neolithic of the Balkans (Dinu 1981) also challenges this hypothesis, while Fechner et al. (2001) have recently found sound soil micromorphological traces of ploughing in Early LBK sites in Belgium.

As there is no reason to suppose that dairying was a 'specific technology' that followed strict rules of cultural transmission and diffusion, a third hypothesis is that domestic animals were exploited for milk to different degrees throughout the Neolithic, depending on specific cultural, economic and environmental factors. For example, it is reasonable to assume that cattle were only intensively exploited for their milk by populations with greater access to pasture. The increased prominence of cattle remains at Early Neolithic sites on the Northern European plain supports this assumption (Bogucki 1984a, b; Midgley 1992: 


\section{Dairy food production in Europe}

372). Furthermore, modern-day native cattle from this region demonstrate high allelic diversity specifically in their milk protein genes, suggesting that their ancestors were selected for increased milk yields. Interestingly, Europe's highest frequency of lactose-tolerant human populations are also found in north central Europe suggesting that the ability to consume milk co-evolved with cattle dairying (Beja-Pereira et al. 2003).

The findings reported here raise previously expressed doubts (Sherratt 1981) as to whether Early Neolithic European farmers had the necessary genetic adaptation to be able to digest lactose in fresh milk. However, even if they did not, they would have been able to produce a wide range of low-lactose, storable products by fermenting milk, as frequently observed in present-day European societies. Indeed, the presence of milk fats and lipid pyrolysis products (i.e. mid-chain ketones) on some of the ceramics analysed suggest that the dairy products were heated, perhaps as part of their processing into lactose-free food products. The mixing of dairy products with other fatty ingredients either at the same time or during the vessel's use-life is also suggested by the heterogeneity of the $\Delta^{13} \mathrm{C}$ values (Figure 3).

The findings also raise two other important questions: Which species were milked? What was the scale of the dairy production?

Whilst stocks of sheep and goats reared in the European Early Neolithic had been domesticated at least two millennia earlier, the question of whether European cattle were domesticated from local wild aurochs or have an earlier Asian ancestry is debated (Bökönyi 1992a: 205; Uerpmann 1996). The genetic analysis of modern breeds of cattle implicates the Near East as the primary centre for cattle domestication, although the timing of this event is unclear (Loftus et al. 1999; Troy et al. 2001). At Ecsegfalva, the small numbers of gracile cattle bone present appear to derive from a long-domesticated stock. Identification of the species of animal milked is also relevant to this debate; goats and sheep could have been milked from an early time, but milking of recently domesticated, huge, native aurochs must have been a more daunting prospect. Therefore if cattle were milked at this time, they were likely to have been domesticated earlier. Furthermore, distinguishing cattle from caprine dairying is important for assessing the role of these animals in the broader economy and society. The less than 20 per cent contribution of cattle bone to the number of identifiable specimens (NISP) at four major Körös culture sites in the Great Hungarian Plain (Figure 2, top) shows that cattle were not greatly exploited.

The animal bone assemblages offer two possible interpretations:

1. Large, uniparous domesticates with long gestation are characterised in the archaeozoological record by longevity: their inconsiderate slaughter would not only represent a major loss, but also contradict secondary exploitation. It is thus possible that a few cows were kept for milk, as by transhumant shepherds (less than 10 per cent of the stock) moving around in Moldavia and Walachia between 1830 and 1846 (Bartosiewicz 1999: 49, Figure 2). Milk certainly produces far more protein per individual than would meat. Dairying, therefore, is an attractive solution when only small numbers of animals are kept. Without contextual information, however, ethnographic analogies should not be taken at face value.

2. A small number of cattle may have been kept for beef and regularly culled, i.e. their role was altogether rather small in food production. Sheep and goat would have provided both meat and milk. The milk yield of goats tends to be higher than that of sheep. The 


\section{O.E. Craig et al.}

c. 6/1 over-representation of identifiable sheep bones relative to those of goat at many sites in Hungary (Bartosiewicz 1999: 56) may thus be a sign of goats being killed less frequently as producers of milk.

Evidently, these two hypotheses can only be tested using multidisciplinary evidence, beyond comparing species frequencies in excavated materials. Research is currently underway to establish the species of absorbed milk present on the pots, through the identification of milk proteins using antibodies specific for the bovine form of $\alpha_{\mathrm{s} 1}$-casein (Craig \& Collins 2000; Craig 2002). So far, analyses of over eighty Neolithic sherds, including all the samples reported here, have not securely identified any potsherds containing bovine milk proteins. Whilst this might suggest that caprines were the only animals milked, degradation and loss of proteins during the period of burial is equally plausible and is currently being assessed.

Identification of milk residues provides little information about the scale or intensity of dairying. It is impossible to tell how frequently a ceramic vessel was used to process dairy products: indeed the organic residue that remains may be solely derived from the last or even the first use of the vessel. Milk may also form a stable organic residue much more readily than other foodstuffs. Furthermore, interpretations of scale based only on ceramic residue evidence do not take into account the many other forms of material culture that may have been used to process dairy products. However, the fact that milk residues were found on pottery from sites over two hundred kilometres apart suggests, at least, that this practice was established over a broad geographical area.

Reconstruction of kill-off patterns from animal assemblages may provide more information concerning the scale of dairying at archaeological sites (Bogucki 1984a; Greenfield 1988; Legge 1981). Whilst this approach has its own methodological problems (Halstead 1998) and is undoubtedly insensitive to small-scale, household or occasional practices, the parameters for intensive milk production have been well defined (Payne 1973).

At Ecsegfalva and Schela Cladovei, the faunal assemblages are too small to accurately reconstruct the mortality profiles (Pike-Tay et al. 2004). However, a larger sheep assemblage has been studied from the Körös site, Endrôd 119 (Bökönyi 1992a). In this study, the age at death profile and the adult ewe to ram ratio are not consistent with kill-off patterns optimised either for dairying or for meat production, suggesting a possible mixed strategy, where dairying was practised on a small-scale. At Ecsegfalva, other indications point towards small-scale household herding rather than extensive pastoralism. The arable weed flora on land close to the site indicates that manuring was practised (Bogaard et al. forthcoming) and patterns of microwear suggestive of overgrazing have been observed on the sheep's teeth (Mainland forthcoming). Both these suggest the enclosure of animals on restricted patches of land and their integration with other local economic practices, rather than large-scale pastoralism where large numbers of animals were moved around the landscape.

In conclusion, we suggest that dairying was practised by some of Europe's earliest farmers. At the sites studied where dairy products were identified, this was most likely a smallscale activity practiced by individual 'homesteads' and constituted part of a broad-based economy, comprising grain cultivation and the exploitation of domesticated animals for both milk and meat. On the sites under discussion here, these were most intensively supplemented by hunting, fishing, fowling and gathering wild plants, especially at the early 
site of Schela Cladovei in the Iron Gates gorge (Bonsall et al. 1997; Bartosiewicz et al. 2001; Gál forthcoming). Finally, dairy products may have had special significance within the overall economy, because, like grain, they can be stored and accumulated.

\section{Note on analytical procedure}

Each sherd was first cleaned with a high-speed drill to eliminate any surface contamination. Ceramic was then drilled from the interior surface. The ceramic powder was weighed and sealed in glass vials prior to all analyses. Samples were also taken from the exterior surface to provide negative controls. Replica 'experimental' ceramics used to boil fresh cows' milk and beef were also used as controls. Procedural blanks were included in all subsequent analyses. Where possible soil samples, either adhering to the sherds themselves or from the same context were analysed to assess post-depositional contamination.

Lipids were solvent extracted and analysed by GC or GCMS using established protocols (Charters et al. 1993; Dudd et al. 1999). Fatty acid methyl esters (FAMEs) were prepared by methylation of saponified solvent extracts using $\mathrm{BF}_{3}$-methanol complex. FAMEs were then extracted using diethyl ether and analysed by gas chromatography combustion isotope ratio mass spectrometry (GC-C-IRMS) using a Hewlett Packard 5890 gas chromatograph attached to a PDZ Europa Geo isotope ratio mass spectrometer using a $60 \mathrm{~m} \times 0.32 \mathrm{~mm}$ fusedsilica column coated with BPX70 stationary phase. Temperature programme $=130^{\circ} \mathrm{C}(2 \mathrm{~min}) ; 130^{\circ}-190^{\circ} \mathrm{C}$ at $4^{\circ} \mathrm{C} \mathrm{min}^{-1} ; 190^{\circ} \mathrm{C}(2 \mathrm{~min})$. The values were corrected for derivatisation. Extracts were run at least in duplicate with analytical precision of $\pm 0.3 \%$. Where available sherds were re-extracted and the data combined.

\section{Acknowledgements}

We thank the Natural Environment Research Council for financial support for this project (GR3/12827). Grateful thanks go to Prof. Geoff Bailey and two anonymous referees for their useful comments on preliminary versions of this manuscript. We also thank Nur Yusof for her initial experimental work on the Ecsegfalva samples carried out at Bradford University. Fieldwork at Ecsegfalva was supported by The British Academy, The Humanities Research Board, The Arts and Humanities Research Board, The Society of Antiquaries of London, The Prehistoric Society, and Cardiff University. Grateful thanks are due to colleagues at the Institute of Archaeology, Hungarian Academy of Sciences, Budapest, and the Munkácsy Mihály Museum, Békéscsaba, Co. Békés, for cooperation; the support of Professor Csanád Bálint, Dr Eszter Bánffy and Dr Imre Szatmári has been invaluable. Finally we especially thank Clive Bonsall for providing access to pottery from Schela Cladovei.

\section{References}

Bartosiewicz, L. 1999. The role of sheep versus goat in meat consumption at archaeological sites, in L. Bartosiewicz \& H. Greenfield (ed.) Transhumant pastoralism in Southern Europe: 47-60. Budapest: Archaeolingua Kiadó.

-forthcoming. The mammalian bone, in A. Whittle (ed.) The Early Neolithic on the Great Hungarian Plain: investigations of the Körös culture site of Ecsegfalva 23, Co. Békés.

Bartosiewicz, L., V. Boroneanţ, C. Bonsall \& S. Stallibrass. 2001. New data on the prehistoric fauna of the Iron Gates: a case study from Schela Cladovei, Romania, in R. Kertész \& J. Makkay (ed.) From the Mesolithic to the Neolithic: 15-22. Budapest: Archaeolingua.
Beja-Pereira, A., G. Luikart, P.R. England, D.G. Bradley, O.C. Jann, G. Bertorelle, A.T. Chamberlain, T.P. Nunes, S. Metodiev, N. Ferrand \& G. Erhardt. 2003. Gene-culture coevolution between cattle milk protein genes and human lactase genes. Nature Genetics 35: 311-3.

Bogaard, A., G. Jones \& J. Bending. forthcoming. The plant remains, in A. Whittle (ed.) The Early Neolithic on the Great Hungarian Plain: investigations of the Körös culture site of Ecsegfalva 23, Co. Békés.

Bogucki, P. 1984a. The antiquity of dairying in temperate Europe. Expedition 28: 51-8.

$-1984 \mathrm{~b}$. Linear pottery ceramic sieves and their economic implications. Oxford Journal of Archaeology 3: 15-30. 


\section{O.E. Craig et al.}

-1996. The spread of early farming in Europe. American Scientist 84: 242-53.

ВӧкӧNYI, S. 1974. History of domestic animals in Central and Eastern Europe. Budapest: Akadémiai Kiadó.

-1981. Early Neolithic vertebrate fauna from Lánycsók-Égettmalom. Acta Archaeologica Academiae Scientiarum Hungaricae 33: 21-34.

-1988 . The neolithic fauna of Divostin, in A. McPherron \& D. Srejović (ed.) Divostin and the Neolithic of Central Serbia: 419-45. Ethnolology monograph 10. Pittsburgh: Department of Anthropology, University of Pittsburgh.

-1992a. The Early Neolithic vertebrate fauna of Endrōd 119, in S. Bökönyi (ed.) Cultural and landscape changes in South-East Hungary I. Reports on the Gyomaendröd project: 195-300. Budapest: Archaeolingua.

$-1992 \mathrm{~b}$. Animal remains of Mihajlovac-Knjepište, an early Neolithic settlement of the Iron Gate Gorge. Balcanica 23: 77-87.

Bonsall, C., R. Lennon, K. McSweeney, C. Stewart, D. Harkness, V. Boroneant, L. Bartosiewicz, R. Payton \& J. Chapman. 1997. Mesolithic and early Neolithic in the Iron Gates: a palaeodietary perspective. Journal of European Archaeology 5: 50-92.

Bonsall, C., M.G. Macklin, R.W. Payton \& A. Boroneanţ. 2000. Climate, floods and river gods: environmental change and the Meso-Neolithic transition in southeast Europe. Before Farming: the archaeology of hunter-gatherers 3-4(2): 1-15.

Boroneanţ, V., C. Bonsall, K. McSweeney, R. Payton \& M. Macklin. 1999. A Mesolithic burial area at Schela Cladovei, Romania, in A. Thévenin (ed.) L'Europe des derniers chasseurs, Épipaléolithique et Mésolithique: 385-90. Paris: Éditions du CNRS.

Bronk Ramsey, C., T. Higham \& A. Whittle. forthcoming. Radiocarbon dating and Bayesian modelling, in A. Whittle (ed.) The Early Neolithic on the Great Hungarian Plain: investigations of the Körös culture site of Ecsegfalva 23, Co. Békés.

Chapman, J.C. 1982. The 'Secondary Products Revolution' and the limitations of the Neolithic. Bulletin of the Institute of Archaeology (London) 19: 107-22.

Charters, S., R.P. Evershed, L.J. Goad, A. Leyden, P.W. Blinkhorn \& V. Denham. 1993. Quantification and distribution of lipid in archaeological ceramics: implications for sampling potsherds for organic residue analysis and the classification of vessel use. Archaeometry 35: 211-23.

Copley, M.S., R. Berstan, S.N. Dudd, G. Docherty, A.J. Murkherjee, V. Straker, S. Payne \& R.P. Evershed. 2003. Direct chemical evidence for widespread dairying in prehistoric Britain. Proceedings of the National Academy of Sciences of the USA 100: 1524-29.
Craig, O.E. 2002. The development of dairying in Europe: potential evidence from food residues on ceramics. Documenta Praehistorica 29: 97-107.

Craig, O.E. \& M.J. Collins. 2000. An improved method for the immunological detection of mineral bound protein using hydrofluoric acid and direct capture. Journal of Immunological Methods 236: 89-97.

Dinu, M. 1981. Clay models of wheels discovered in Copper Age cultures of Old Europe mid-fifth millennium B.C. Journal of Indo-European Studies 9: $1-14$.

Dudd, S.N. \& R.P. Evershed. 1998. Direct demonstration of milk as an element of archaeological economies. Science 282: 1478-81.

Dudd, S.N., R.P. Evershed \& A.M. Gibson. 1999. Evidence for varying patterns of exploitation of animal products in different prehistoric pottery traditions based on lipids preserved in surface and absorbed residues. Journal of Archaeological Science 26: 1473-82.

ENSER, M. 1991. Animal carcass fats and fish oils, in J.B. Rosell \& J.L.R. Protchard (ed.) Analysis of oilseed, fats and fatty foods: 329-94. London: Elsevier.

Evershed, R.P., S.N. Dudd, M.S. Copley \& A. MutherJeE. 2002. Identification of animal fats via compound specific $\delta^{13} \mathrm{C}$ values of individual fatty acids: assessments of results for reference fats and lipid extracts of archaeological pottery vessels. Documenta Praehistorica 21: 73-96.

Evershed, R.P., A.W. Stott, A. Raven, S.N. Dudd, S. Charters \& A. Leyden. 1995. Formation of long-chain Ketones in ancient-pottery vessels by pyrolysis of acyl lipids. Tetrahedron Letters 36: 8875-8.

Fechner, K., R. Baes \& Y. Devos. 2001. Using ad hoc checklists for identifying archaeological structures. Paper presented at First International Conference on Soils and Archaeology, Százhalombatta, Hungary 30/V-3/VI/2001.

Friedli, H., H. Lotscher, H. Oeschger, U. Siegenthaler \& B. Stauffer. 1986. Ice core record of the ${ }^{13} \mathrm{C} /{ }^{12} \mathrm{C}$ ratio of atmospheric $\mathrm{CO}_{2}$ in the past two centuries. Nature 324: 237-8.

Gál, E. forthcoming. Aspects of Neolithic Bird Hunting in Hungary, in D.W. Bailey \& A. Whittle (ed.) Sedentism, settlement and the Neolithic of Central and Southeastern Europe. Oxford: Oxbow.

Greenfield, H.J. 1988. The origins of milk production in the Old World - a zooarchaeological perspective from the Central Balkans. Current Anthropology 29: 573-93.

GRÜss, J. 1933. Über Milchreste aus der Hallstattzeit und andere Funde. Forschungen und Fortschritte 9: 105-6. 


\section{Dairy food production in Europe}

Halstead, P. 1998. Mortality models and milking: problems of uniformitarianism, optimality and equifinality reconsidered. Anthropozoologica 27: 3-20.

Hodder, I. 1990. The domestication of Europe. Oxford: Blackwell.

Holmes, W. 1970. Animals for food. Proceedings of the Nutritional Society 29: 273-81.

LegGe, A.J. 1981. The agricultural economy, in R. Mercer (ed.) Grimes Graves, Norfolk excavations 1971-72: 79-118. London: Archaeological Reports.

Loftus, R.T., O. Ertugrul, A.H. Harba, M.A. El-Barody, D.E. MacHugh, S.D. Park \& D.G. BradLey. 1999. A microsatellite survey of cattle from a centre of origin: the Near East. Molecular Ecology. 8: 2015-22.

MaInland, I. forthcoming. A microwear analysis of selected sheep and goat mandibles, in A. Whittle (ed.) The Early Neolithic on the Great Hungarian Plain: investigations of the Körös culture site of Ecsegfalva 23, Co. Békés.

Midgley, M. 1992. TRB culture. The first farmers of the north European plain. Edinburgh: Edinburgh University Press.

Moore, J.H. \& W.W. Christie. 1981. Digestion, absorption and transport of fats in ruminant animals, in W.W. Christie (ed.) Progress in lipid research: 227-77. Oxford: Pergamon.

Oross, K. forthcoming. The pottery, in A. Whittle (ed.) The Early Neolithic on the Great Hungarian Plain: investigations of the Körös culture site of Ecsegfalva 23, Co. Békés.

PAyne, S. 1973. Kill-off patterns in sheep and goats. Anatolian Studies 23: 281-303.

Pike-Tay, A., L. Bartosiewicz, E. Gál \& A. Whittle. 2004. Body-part representation and seasonality: sheep/goat, bird and fish remains from early Neolithic Ecsegfalva 23, SE Hungary. Journal of Taphonomy 2/4: 221-46.

Raven, A.M., P.F. van Bergen, A.W. Stott, S.N. DudD \& R.P. EvERSHED. 1997. Formation of long-chain ketones in archaeological pottery vessels by pyrolysis of acyl lipids. Journal of Analytical and Applied Pyrolysis 40: 267-85.
Richards, M.P. 2000. Human consumption of plant foods in the British Neolithic; direct evidence from bone stable isotopes, in A. Fairbairn (ed.) Plants in Neolithic Britain and beyond: 123-35. Oxford: Oxbow.

Sherratt, A. 1981. Plough and pastoralism: aspects of the secondary products revolution, in I. Hodder, G. Isaac \& N. Hammond (ed.) Pattern of the past: studies in honour of David Clarke: 261-305. Cambridge: Cambridge University Press.

-1983 . The secondary exploitation of animals in the Old World. World Archaeology 15: 90-104.

-1997. Economy and society in prehistoric Europe: changing perspectives. Edinburgh: Edinburgh University Press.

Troy, C.S., D.E. MacHugh, J.F. Bailey, D.A. Magee, R.T. Loftus, P. Cunningham, A.T. Chamberlain, B. Sykes \& D.G. Bradley. 2001. Genetic evidence for Near-Eastern origins of European cattle. Nature 410: 1088-91.

Uerpmann, H.-P. 1996. Animal domestication accident or intention?, in D.R. Harris (ed.) The origins and spread of agriculture and pastoralism in Eurasia: 227-37. Washington: Smithsonian.

Whittle, A. 1985. Neolithic Europe. A new synthesis. Cambridge: Cambridge University Press.

-1996. Europe in the Neolithic: the creation of new worlds. Cambridge: Cambridge University Press.

-2000. New research on the Hungarian Early Neolithic. Antiquity 74: 13-14.

-(ed.) forthcoming. The Early Neolithic on the Great Hungarian Plain: investigations of the Körös culture site of Ecsegfalva 23, Co. Békés.

Whittle, A., L. Bartosiewicz, D. Borić, P. Pettitt \& M. Richards. 2002. In the beginning: new radiocarbon dates for the Early Neolithic in northern Serbia and south-east Hungary. Antaeus 25: 63-117. 